\title{
Efektivitas Fototerapi Terhadap Penurunan Kadar Bilirubin Total pada Hiperbilirubinemia Neonatal di RSUP Sanglah
}

\author{
Ayu Ketut Surya Dewi, I Made Kardana, Ketut Suarta \\ Bagian/SMF Ilmu Kesehatan Anak, Fakultas Kedokteran Universitas Udayana/ RSUP. Sanglah, Denpasar
}

\begin{abstract}
Latar belakang. Enampuluh persen bayi lahir normal berkembang menjadi kuning dalam satu minggu pertama kehidupan. Fototerapi merupakan salah satu tatalaksana mengurangi hiperbilirubinemia melalui proses fotoisomerisasi dan isomerisasi struktural.

Tujuan. Mengetahui jumlah penurunan kadar serum bilirubin total pada bayi hiperbilirubinemia usia gestasi $\geq 35$ minggu setelah dilakukan fototerapi selama 24 jam, agar dapat memprediksi lama perawatan fototerapi di rumah sakit.

Metode. Penelitian cohort dengan melibatkan 44 bayi hiperbilirubinemia usia kehamilan $\geq 35$ minggu, melihat kadar bilirubin sebelum dan setelah dilakukan fototerapi. Analisis data dan statistik digunakan SPSS 22 dan uji t berpasangan dengan nilai $\mathrm{p} \leq 0,05$ dan koefisien interval 95\% dianggap signifikan.

Hasil. Rerata usia kuning 4,2 $\pm 0,88$ hari dengan rerata berat badan $2784 \pm 643$ gram. Rerata kadar bilirubin sebelum dilakukan fototerapi 15,3 $\pm 1,94 \mathrm{mg} / \mathrm{dL}$, dan setelah dilakukan fototerapi 24 jam 12,8 $\pm 1,88 \mathrm{mg} / \mathrm{dL}$ dengan p=0,001. Penurunan kadar bilirubin $2,5 \pm 0,8 \mathrm{mg} / \mathrm{dL}$ dalam 24 jam (turun 16,3\% dalam 24 jam). Komplikasi fototerapi yaitu hipertermi (2,3\%) dan eritema (27,3\%).

Kesimpulan. Penurunan kadar bilirubin setelah dilakukan fototerapi selama 24 jam $2,5 \pm 0,8 \mathrm{mg} / \mathrm{dL}$ (turun $16,3 \%$ ). Sari Pediatri 2016;18(2):81-6
\end{abstract}

Kata kunci: hiperbilirubinemia, bayi baru lahir, fototerapi

\section{Phototherapy Effectiveness of Reduce Total Bilirubin Level in Hyperbilirubinemia Neonates at Sanglah Hospital}

\author{
Ayu Ketut Surya Dewi, I Made Kardana, Ketut Suarta
}

Background. Some $60 \%$ of normal newborns become clinically jaundiced sometime during the first week of life. Phototherapy is one of the treatments to reduce hyperbilirubinemia through photo isomerization process and structural isomerization.

Objective. The aim of this study was to determine the amount of reduction in serum levels of total bilirubin in hyperbilirubinemia infants after 24 hours of phototherapy, in order to predict the duration of phototherapy requirement in the hospital.

Methods. Cohort study, involving 44 children with hyperbilirubinemia with gestational age $\geq 35$ weeks, with knowledge regarding their bilirubin levels before and after phototherapy. SPSS 22 program was used for data analysis, and paired t test and p-values $\leq 0.05$ and $95 \%$ CI were considered statistically significant.

Results. Mean age of jaundice newborn was $4.2 \pm 0.88$ days with a mean weight $2784 \pm 643$ gram. Mean bilirubin levels prior to phototherapy was $15.3 \pm 1.94 \mathrm{mg} / \mathrm{dL}$, and after 24 hours of phototherapy mean bilirubin levels was $12.8 \pm 1.88 \mathrm{mg} / \mathrm{dL}, \mathrm{p}=0,001 \mathrm{with}$ mean reduction of bilirubin level of $2.5 \pm 0,8 \mathrm{mg} / \mathrm{dL} / 24$ hours (decreased $16.3 \%$ in 24 hours). Observed complications of phototherapy during this study were hyperthermia (2.3\%) and erythema $(27.3 \%)$.

Conclusions. Mean reduction of bilirubin level after 24 hours of phototherapy was $2.5 \pm 0,8 \mathrm{mg} / \mathrm{dL}$ ( $16.3 \%$ reduction) Sari Pediatri 2016;18(2):81-6

Keywords: hyperbilirubinemia, newborn, phototherapy

Alamat korespondensi: Dr. Ayu Ketut Surya Dewi. Bagian/SMF Ilmu Kesehatan Anak, Fakultas Kedokteran Universitas Udayana/ RSUP. Sanglah, Denpasar. E-mail: suryadewi.ped@gmail.com 
Ayu Ketut Surya Dewi dkk: Efektivitas fototerapi terhadap penurunan kadar bilirubin total neonatal

$\mathrm{K}$

uning merupakan suatu keadaan yang sering terjadi pada neonatus. Salah satu penyebab mortalitas pada bayi baru lahir adalah 2 komplikasi ikterus neonatorum yang paling berat. ${ }^{1}$ Ikterus merupakan gambaran klinis berupa pewarnaan kuning pada kulit dan mukosa karena unconjugated bilirubin yang tinggi. ${ }^{1,2}$

Di Amerika Serikat, sekitar 65\% bayi mengalami ikterus. Penelitian yang dilakukan Chime $\mathrm{dkk}^{3} \mathrm{di}$ Nigeria tahun 2011 didapatkan prevalensi ikterus neonatorum 33\% dengan $21 \%$ lelaki dan $12 \%$ perempuan. Di Indonesia, insiden ikterus pada bayi cukup bulan di beberapa Rumah Sakit (RS) Pendidikan, antara lain, RSCM, RS. Dr Sardjito, RS Dr. Soetomo, RS. Dr. Kariadi bervariasi antara 13,7 hingga 85\%. ${ }^{1}$ Berdasarkan data registrasi Neonatologi bulan Desember 2014 sampai November 2015, di antara 1093 kasus neonatus yang dirawat, didapatkan 165 (15,09\%) kasus dengan ikterus neonatorum.

Tata laksana hiperbilirubinemia bertujuan untuk mencegah agar kadar bilirubin indirek dalam darah tidak mencapai kadar yang neurotoksik. Tata laksana terkini, meliputi pemberian air susu ibu (ASI), fototerapi, dan tranfusi tukar. ${ }^{2}$ Penggunaan fototerapi sebagai salah satu terapi hiperbilirubinemia telah dimulai sejak tahun 1950 dan efektif dalam menurunkan insiden kerusakan otak (kern ikterus) akibat hiperbilirubinemia. ${ }^{4-6}$ Keuntungan fototerapi, antara lain, tidak invasif, efektif, tidak mahal, dan mudah digunakan. ${ }^{2,7}$ Fototerapi mengurangi hiperbilirubinemia melalui proses fotoisomerisasi dan isomerisasi struktural. ${ }^{8}$

Efektivitas fototerapi tergantung pada kualitas cahaya yang dipancarkan lampu (panjang gelombang), intensitas cahaya (iradiasi), luas permukaan tubuh, jarak lampu fototerapi. ${ }^{910}$ Penelitian Seidman dkk, ${ }^{11}$ tentang konsentrasi penurunan bilirubin setelah dilakukan fototerapi dengan light emiting devices (LED) blue, blue-green, dan konvensional tidak ada perbedaan yang signifikan. ${ }^{11}$ Fototerapi yang intensif seharusnya dapat menurunkan kadar bilirubin total serum 1-2 mg/dL dalam 4-6 jam. ${ }^{12}$ Penelitian Brandao $\mathrm{dkk},{ }^{10}$ mendapatkan penurunan kadar bilirubin total setelah fototerapi $0,16 \pm 0,08 \mathrm{mg} / \mathrm{dL} / \mathrm{jam}$ atau turun $3,84 \pm 1,92 \mathrm{mg} / \mathrm{dL}$ dalam 24 jam. Perlu diperhatikan efek samping fototerapi, antara lain, dapat timbul eritema, dehidrasi, hipertermi, diare, dan kerusakan retina. ${ }^{2,12,13}$
Tujuan penelitian adalah untuk mengetahui penurunan kadar serum bilirubin total pada bayi hiperbilirubinemia usia gestasi $\geq 35$ minggu setelah dilakukan fototerapi selama $24 \mathrm{jam}$. Hal ini diperlukan untuk memprediksi lama perawatan bayi dengan hiperbilirubinemia yang memerlukan fototerapi di rumah sakit.

\section{Metode}

Desain penelitian kohort dilakukan di Sub-Bagian Neonatologi / SMF Ilmu Kesehatan Anak FK Unud/ RSUP Sanglah pada bulan Februari sampai dengan Oktober 2015. Kriteria inklusi adalah pasien rawat inap di ruang perawatan neonatus RSUP Sanglah Denpasar, bayi dengan usia kehamilan $\geq 35$ minggu, berat badan lahir $\geq 2200$ gram, mengalami hiperbilirubinemia yang memerlukan fototerapi, hiperbilirubinemia terjadi pada hari ke 2 hingga hari ke- 5 setelah lahir, dan orang tua setuju ikut serta dalam penelitian. Kriteria eksklusi adalah bayi dengan kadar hiperbilirubinemia yang memerlukan tindakan tranfusi tukar, bayi dengan kelainan kongenital mayor, riwayat asfiksia saat lahir, bayi dengan sepsis neonatorum, bayi dengan penyakit hemolitik (diagnosis inkomptabilitas ABO, Rhesus).

Sampel dipilih secara consecutive sampling, rumus untuk penelitian perhitungan besar sampel digunakan rumus besar sampel untuk uji hipotesis terhadap dua rerata kelompok berpasangan ${ }^{14}$ dengan derivat baku alfa untuk $\alpha=0,05$ dengan tingkat kepercayaan 95\%, besar sampel minimal adalah 44 subjek. Data dasar subjek penelitian, yaitu diagnosis, usia, jenis kelamin, usia kehamilan, berat badan lahir, kadar bilirubin sebelum dan sesudah fototerapi, dan komplikasi fototerapi diperoleh dari rekam medis dan anamnesis langsung dari keluarga subjek, disesuaikan dengan kuesioner yang terlampir.

Definisi operasional variabel hiperbilirubinemia adalah terjadinya peningkatan kadar plasma bilirubin 2 standar deviasi atau lebih dari kadar yang diharapkan berdasarkan umur bayi atau lebih dari persentil 90 dan dilakukan dengan metode spektrofotometri. Kelainan kongenital mayor adalah kelainan yang sudah ada sejak lahir yang dapat disebabkan oleh faktor genetik maupun non genetik yang memerlukan tindakan medis segera untuk mempertahankan kelangsungan hidup. Sepsis neonatorum adalah infeksi aliran darah neonatus yang bersifat invasif dan ditandai dengan hasil kultur 
atau biakan darah positif

Kadar bilirubin adalah kadar bilirubin total darah, yaitu bilirubin terkonjugasi dan bilirubin tidak terkonjugasi. Metode pengukuran yang digunakan adalah fotometri atau spektrofotometri yang mengukur intensitas warna azobilirubin. Satuan yang digunakan $\mathrm{mg} / \mathrm{dL}$ (skala ratio). Fototerapi adalah terapi sinar yang dilakukan untuk mengubah bentuk isomer bilirubin sehingga dapat larut dalam air (skala nominal). Usia pascanatal adalah usia dari bayi dilahirkan hingga mengalami kuning, dinyatakan dalam satuan hari (skala ordinal).

Analisis data diolah dengan SPSS 22, karakteristik subjek disajikan secara deskriptif dalam bentuk tabel dan narasi. Uji komparabilitas bertujuan untuk membandingkan rerata kadar bilirubin antar kelompok sebelum dan sesudah fototerapi dengan uji T Berpasangan.

Bayi kuning yang memenuhi kriteria inklusi dan eksklusi diambil darah $2 \mathrm{~mL}$ untuk pemeriksaan kadar bilirubin total. Setelah hasil pemeriksaan kadar bilirubin total keluar kemudian diplot ke kurva Buthani. Apabila hasil plot yang dilakukan menyatakan perlu dilakukan fototerapi, bayi tersebut akan digunakan sebagai sampel penelitian. Orang tua bayi diminta menandatangani formulir Informed consent yang telah disediakan.

Fototerapi yang diberikan adalah fototerapi konvensional. Sumber sinar yang digunakan memiliki spesifikasi, lampu fluorescent 4 buah merk Phillips dengan kekuatan masing-masing 20 Watt, panjang gelombang yang digunakan 420-470 um, intensitas cahaya $10 \mu \mathrm{W} / \mathrm{cm}^{2} / \mathrm{nm}$, jarak antara bayi dan sumber sinar $30 \mathrm{~cm}$, dan digunakan alas linen putih pada basinet atau inkubator dan tirai putih di sekitar daerah unit terapi sinar untuk memantulkan cahaya sebanyak mungkin kepada bayi.
Fototerapi diberikan secara berkelanjutan dan hanya dihentikan saat bayi menyusu atau dimandikan. Saat fototerapi bayi telanjang, hanya digunakan penutup mata berwarna putih dan popok, dan fototerapi diberikan selama $24 \mathrm{jam}$. Setelah fototerapi selesai, dilakukan pengambilan sampel darah $2 \mathrm{~mL}$ untuk pemeriksaan kadar bilirubin total setelah fototerapi.

\section{Hasil}

Di antara 44 subjek didapatkan $28(63,6 \%)$ lelaki dan $16(36,4 \%)$ perempuan. Tigabelas $(29,5 \%)$ pasien dengan usia kehamilan $\geq 35$ sampai $<37$ minggu dan $31(70,5 \%)$ dengan usia $\geq 37$ sampai $\leq 42$ minggu. Rerata usia saat kuning 4,2 hari dan rerata berat badan $2784 \pm 643$ gram. Karakteristik subjek penelitian tertera pada Tabel 1 .

Rerata kadar bilirubin total sebelum dilakukan fototerapi $15,3 \pm 1,94 \mathrm{mg} / \mathrm{dL}$ dan setelah dilakukan fototerapi 24 jam 12,8 $\pm 1,88 \mathrm{mg} / \mathrm{dL} /$ hari. Penurunan kadar bilirubin $2,5 \pm 0,8 \mathrm{mg} / \mathrm{dL}$ dalam 24 jam (turun $16,3 \%$ dalam 24 jam) dengan $\mathrm{p}=0,001$.

Tabel 1. Karakteristik subjek $(\mathrm{n}=44)$

\begin{tabular}{ll}
\hline Variabel & $\mathrm{N}=44$ \\
\hline $\begin{array}{l}\text { Usia saat kuning, rerata, SB (hari) } \\
\text { Berat badan, rerata, SB (gram) }\end{array}$ & $4,2 \pm 0,88$ \\
Jenis kelamin & $2784 \pm 643$ \\
$\quad$ Laki-laki,n (\%) & \\
$\quad$ Perempuan,n(\%) & $28(63,6 \%)$ \\
Usia kehamilan (minggu) & $16(36,4 \%)$ \\
$35-<37$ & $13(29,5 \%)$ \\
$37-42$ & $31(70,5 \%)$ \\
\hline
\end{tabular}

Tabel 2. Kadar bilirubin pre dan pasca fototerapi berdasarkan usia kehamilan

\begin{tabular}{llllll}
\hline Usia kehamilan $(\mathrm{minggu})$ & Pre fototerapi & Pasca fototerapi & $\begin{array}{l}\text { Penurunan } \\
\text { bilirubin }\end{array}$ & IK95\% & $\mathrm{p}$ \\
\hline 35- $<37$, rerata $\pm(\mathrm{SB}), \mathrm{mg} / \mathrm{dL} / \mathrm{hari}$ & $14,71 \pm 2,05$ & $12,45 \pm 1,92$ & $2,25 \pm 0,69$ & $1,83-2,6$ & 0,001 \\
37-42, rerata $\pm(\mathrm{SB}), \mathrm{mg} / \mathrm{dL} /$ hari & & $12,99 \pm 1,87$ & $2,6 \pm 0,86$ & $2,32-2,95$ & 0,001 \\
& & & & &
\end{tabular}

*; uji t berpasangan 
Kadar bilirubin pada usia kehamilan 35 sampai $<37$ minggu dengan rerata penurunan kadar bilirubin $2,25 \mathrm{mg} / \mathrm{dL} / 24 \mathrm{jam}$, dan pada usia 37-42 minggu dengan kadar 2,6 mg/dL/24 jam (Tabel 2).

Komplikasi jangka pendek fototerapi, yaitu hipertermi $1(2,3 \%)$ dan eritema $12(27,3 \%)$ pasien.

\section{Pembahasan}

Ikterus merupakan gambaran klinis berupa pewarnaan kuning pada kulit dan mukosa karena kadar unconjugated bilirubin meningkat. ${ }^{1,2}$ Sejak diperkenalkan pada tahun 1958, fototerapi merupakan salah satu terapi untuk hiperbilirubinemia neonatal. ${ }^{15}$ Enampuluh persen bayi yang lahir normal berkembang menjadi kuning dalam satu minggu pertama kehidupan.

Mekanisme ikterus melalui peningkatan produksi bilirubin karena jumlah sel darah merah yang lebih tinggi, umur sel darah merah lebih singkat sehingga pemecahan sel lebih cepat. Mekanisme lainnya karena penurunan ekskresi bilirubin melalui penurunan uptake dalam hati, penurunan konjugasi oleh hati, peningkatan sirkulasi enterohepatik. Ekskresi bilirubin membaik setelah usia 1 minggu dan $1 \%-2 \%$ bayi dengan usia kehamilan 35 minggu dengan kadar bilirubin $20 \mathrm{mg} / \mathrm{dL}^{2,15,16}$

Tujuan fototerapi adalah mengonversi bilirubin menjadi photoisomers kuning dan produk oksidasi tidak berwarna yang kurang lipofilik dari bilirubin dan tidak memerlukan konjugasi hepar untuk ekskresi. Photoisomers diekskresikan terutama dalam empedu dan produk oksidasi terutama di urin. ${ }^{16-18}$

Data dasar subjek penelitian mendapatkan 28 $(63,6 \%)$ lelaki dan $16(36,4 \%)$ perempuan. Penelitian kami sesuai dengan penelitian Najib $\mathrm{dkk}^{19}$ yang melaporkan jenis kelamin lelaki $58,2 \%$, tetapi belum diketahui hubungan antara jenis kelamin dengan risiko ikterus. Tigabelas $(29,5 \%)$ pasien dengan usia kehamilan <37 minggu dan 31 (70,5\%) dengan usia $\geq 37$ sampai $<42$ minggu dengan rerata berat badan $2784 \pm 643$ gram. Sebagian besar subjek merupakan bayi cukup bulan dengan berat sesuai usia kehamilan.

Kami mendapatkan penurunan kadar bilirubin total setelah dilakukan fototerapi $2,5 \pm 0,8 \mathrm{mg} / \mathrm{dL} / 24$ jam (turun 16,3\% dalam 24 jam). Brandao dkk ${ }^{10}$ melaporkan penurunan bilirubin $0,16 \pm 0,08 \mathrm{mg} / \mathrm{dL} /$ jam $(3,84 \pm 1,92) \mathrm{mg} / \mathrm{dL}$ dalam $24 \mathrm{jam}$. Silva $\mathrm{dkk}^{20}$ melaporkan penuruan kadar bilirubin dalam 24 jam pada double fototerapy vs single fototerapy $(5,1 \pm 2,2$ vs $4,3 \pm 2,1) \mathrm{mg} / \mathrm{dL}$. Penelitian Brandao dkk, ${ }^{10}$ penurunan bilirubin total 3,84 $\pm 1,92 / \mathrm{mg} / \mathrm{dL}$ dalam $24 \mathrm{jam}$, lebih tinggi dibandingkan dengan penelitian kami karena jarak antara sinar fototerapi dengan bayi $12 \mathrm{~cm}$, sedangkan pada penelitian kami dengan jarak $30 \mathrm{~cm}$. Semakin dekat paparan sinar fototerapi dengan bayi, semakin efektif untuk menurunkan kadar bilirubin.

Silva $\mathrm{dkk}^{20}$ melaporkan penurunan kadar bilirubin total setelah fototerapi 24 jam pada single fototerapi $4,3 \pm 2,1 \mathrm{mg} / \mathrm{dL}$. Penurunan kadar bilirubin ini lebih tinggi dibandingkan dengan penelitian kami karena usia inklusi lebih lebar, yaitu usia lebih dari 1 hari dan kurang dari 7 hari. Berdasarkan kurva buthani, kadar bilirubin saat usia $\geq 5$ hari bilirubin cenderung mengalami penurunan. ${ }^{17}$ Faktor yang perlu dipertimbangkan dalam menentukan dan melaksanakan fototerapi adalah berbagai emisi dari sumber cahaya, intensitas cahaya (iradiance), luas permukaan tubuh yang difototerapi. Panjang gelombang cahaya yang efektif pada region biru-hijau 460-490 nm. Semakin dekat jarak fototerapi dengan tubuh bayi maka semakin efektif. ${ }^{21}$ Bethanabotla ${ }^{22}$ melaporkan hasil tidak ada perbedaan signifikan posisi saat difototerapi baik posisi supinasi atau berganti posisi karena jumlah area yang difototerapi sama meskipun berubah posisi.

Penurunan kadar bilirubin total terjadi pada bayi usia kehamilan 35-<37 minggu dengan rerata penurunan kadar bilirubin 2,25 $\pm 0,69 \mathrm{mg} / \mathrm{dL} / 24 \mathrm{jam}$,

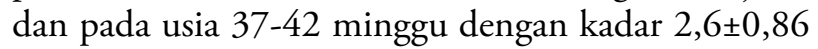
$\mathrm{mg} / \mathrm{dL} / 24 \mathrm{jam}$. Penurunan kadar bilirubin pada bayi kurang bulan lebih sedikit karena hiperbilirubinemia pada bayi prematur lebih sering, lebih berat, dan lebih lama karena jumlah eritrosit lebih banyak, usia eritrosit lebih singkat, sel hati yang masih imatur, uptake dan konjugasi lebih lambat dan sirkulasi enterohepatik meningkat (masukan oral yang tertunda dan kolonisasi bakteri yang terhambat). ${ }^{2,16,17}$

Efek samping jangka pendek pemberian fototerapi adalah gangguan keseimbangan suhu (hipertermi), kehilangan cairan (dehidrasi), gangguan kalsium (hipokalsemi), diare, dan eritema pada kulit. ${ }^{13}$ Pada penelitian kami, komplikasi hipertermi 1 (2,3\%) dan eritema $12(27,3 \%)$ pasien. Komplikasi hipertermi rendah karena jarak fototerapi dengan bayi yang berjarak $30 \mathrm{~cm}$, sedangkan penelitian lain dengan jarak $12 \mathrm{~cm}$. Paparan panas sinar fototerapi dan kurangnya asupan air susu ibu (ASI) yang menyebabkan pasien 
hipertermi dan eritema disebabkan karena paparan sinar dari fototerapi pada bayi yang fotosensitif.

Penelitian kami memiliki beberapa kelemahan, yaitu paparan fototerapi ke bayi yang berjarak $30 \mathrm{~cm}$ karena pengaturan alat fototerapi tidak bisa diturunkan lagi ketinggiannya. Buthani menyarankan semakin dekat jarak dengan paparan fototerapi semakin efektif penurunan bilirubin dan juga memastikan status pasien selama fototerapi, yaitu status hidrasi yang adekuat, status nutrisi, dan kontrol temperatur.

\section{Kesimpulan}

Penurunan kadar bilirubin total setelah dilakukan fototerapi dalam 24 jam sebesar $2,5 \pm 0,8 \mathrm{mg} / \mathrm{dL}$, mengalami penurunan sebesar $16,3 \%$ dalam 24 jam. Disarankan, fototerapi diberikan dengan jarak 10-20 $\mathrm{cm}$, semakin dekat jarak bayi dengan sinar fototerapi semakin efektif dalam menurunkan kadar bilirubin total. Pengaturan ketinggian alat fototerapi yang sudah maksimal dan tidak bisa diturunkan kembali, dengan permasalahan ini diharapkan disediakan box bayi khusus yang cukup tinggi agar jarak bayi dengan alat fototerapi semakin dekat.

\section{Daftar pustaka}

1. Health Technology Assestment. Tatalaksana ikterus neonatorum. HTA Indonesia. Unit pengkajian teknologi kesehatan direktorat jenderal pelayanan medik departemen kesehatan RI. Jakarta; HTA Indonesia; 2004.

2. Gomella TL. Hyperbilirubinemia indirect (unconjugated hyperbilirubinemia). Dalam: Management, procedure, on-call, disease and drug. Seventh edition. Lange; 2009.h.498-510.

3. Chime G, Egenede J, Arute J. Prevalence of Neonatal Jaundice on Central Hospital, Warri, Delta State, Nigeria. Int J Health Res 2011;4:123-6.

4. Hammerman C, Kaplan M. Recent developments in the management of neonatal hyperbilirubinemia. Neoreviews 2000;1:19-23.

5. Philip A. The rise an fall of exchange transfusion. Neoreviews 2000;4:169-74.

6. Ahmed NA, Hamdoon GW. A Prospective randomized controlled study of phototherapy using blue LED and conventional phototherapy in neonatal hyper- bilirubinemia. Iraqi Postgrad Med J 2013;12:668-74.

7. Kappas A. A method for interdicting the development of severe jaundice in newborn by inhibiting the production of bilirubin. Pediatrics 2004;11:119-22.

8. Deorari A, Agarwal R. Unconjugated hyperbilirubinemia in newborns: current perspective. Indian Pediatrics 2002;39:30-42.

9. AAP. Management of hyperbilirubinemia in the newborn infant 35 or more weeks of gestation. Pediatrics. 2004; 114:297-316.

10. Brandao D, Draque C, Sanudo A, Filho G, Almeida $M$. LED versus daylight phototherapy at low irradiance in newborns $\geq 35$ weeks of gestation : randomized controlled trial. J Matern Fetal Neonatal Med 2015;28:172530 .

11. Seidman DS, Moise J, Ergaz Z, Laor A, Vreeman H, Stevenson D, dkk. A prospective Randomized controlled study of phototherapy using blue and blue-green lightemitting devices, and conventional halogen-quartz phototherapy. J Perinatol 2003;23:123-7.

12. Martin C, Cloherry J. Neonatal hyperbilirubinemia. Dalam: Cloherty J, Eichenwald E, Stark A, penyunting. Manual of neonatal care. Edisi ke-5. USA. Lippincot Wiliams \& Walkins;2004.h.185-221.

13. Xiaong T, Cambier S, Mu D. The side effects of phototherapy for neonatal jaundice : what do we know ? What should we do ?. Eur J Pediatr 2011;170:1247-55.

14. Sastroasmoro S. Madiyono B. Perkiraan besar sampel. Dalam: Dasar-dasar metodologi penelitian klinis. Edisi ke-4. Jakarta: Sagung Seto; 2011.h.348-81.

15. Tridente A, De Luca D. Efficacy of light emitting diode versus other light sources for treatment of neonatal hyperbilirubinemia : a systematic review and meta analysis. Acta Paediatrica 2011;110:458-65.

16. Porter ML, Dennis BL. Hyperbilirubinemia in the newborn. Am Fam Physician 2002;65:599-606.

17. Maisels MJ, McDonagh A. Phototherapy for neonatal jaundice. N Engl J Med 2008;358:920-8.

18. American Academic of Pediatrics. Management of hyperbilirubinemia in the newborn infant 35 or more weeks of gestation. Clinical Practice Guideline 2004;114:297-316.

19. Najib KS, Saki F, Hemmati F, Inaloo S. Incidence, risk factors and cause of severe neonatal hyperbilirubinemia in the south of Iran (Fars province). Iran Red Crecent Med J 2013;15:260-3.

20. Silva I, Luco M, Tapia J, Perez M, Salinas J, Flores J, Villaroel L. Single vs double phototherapy in the treatment of full-term newborns with nonhemolytic 
Ayu Ketut Surya Dewi dkk: Efektivitas fototerapi terhadap penurunan kadar bilirubin total neonatal

hyperbilirubinemia. J Pediatr 2009;85:455-8.

21. Buthani VK and the committee on fetus and newborn. Phototherapy to prevent severe neonatal hyperbilirubinemia in the newborn infant 35 or more weeks of gestation. Pediatrics 2011;128:1046-52.
22. Bethanabotla S, Thukral A, Sankar MJ, Paul VK, Deorari AK. Effect of position of infant during phototherapy in management of hyperbilirubinemia in late preterm and term neonates : a randomized controlled trial. J Perinatol 2013;10:195-9. 